\title{
DEVELOPMENT OF RESEARCH AND COMMUNITY SERVICE INFORMATION SYSTEM AT THE INSTITUTE FOR RESEARCH AND COMMUNITY SERVICE UNIVERSITY OF PALANGKA RAYA
}

\author{
Abertun Sagit Sahay ${ }^{\mathrm{a}, 1, *}$, Felicia Sylviana ${ }^{\mathrm{b}, 2}$, Rony Teguh ${ }^{\mathrm{c}, 3}$, Devina ${ }^{\mathrm{d}, 4}$ \\ ${ }^{a}$ Jurusan Teknik Informatika FT UPR, J1 H. Timang Tunjung Nyaho \\ b Jurusan Teknik Informatika FT UPR, J1 H. Timang Tunjung Nyaho \\ ${ }^{\mathrm{c}}$ Jurusan Teknik Informatika FT UPR, Jl H. Timang Tunjung Nyaho \\ dJurusan Teknik Informatika FT UPR, Jl H. Timang Tunjung Nyaho \\ abertun@gmail.com ${ }^{1}$; felicia.upr@gmail.com2; ronyteguh@it.upr.ac.id ${ }^{3}$ \\ * corresponding author
}

ARTICLE INFO

Keywords

application

IRCSUPR

research

community service
ABSTRACT

The Institute for Research and Community Service University of Palangkaraya (IRCS UPR) manages research activities, community services and controls the administration of necessary resources. Therefore, an application is requiredto record a lot of data from the proposal to the final report of research and community servicethat ultimately is expected to be a control and evaluation on the performance of all parties involved.

The methodology used in the development of this application there are several stages ranging from problem identification, needs analysis, design (which includes architecture design, database design, interface design and website navigation design), coding, testing and maintenance. On the testing stage used blackbox testing method.

The results achieved from the making of this application there are 4 actors are administrators, proposers, reviewers and operators who have different access rights in accordance with its function. While from the results of the testing is known that all the functionality of the system is running well in accordance with the required and designed previously.

\section{Pendahuluan}

\subsection{Latar Belakang}

Lembaga Penelitian dan Pengabdian Kepada Masyarakat Universitas Palangka Raya (LPPM UPR) mempunyai tugas melakukan koordinasi dan mendokumentasi pelaksanaan kegiatan penelitian dan pengabdian kepada masyarakat serta ikut mengusahakan pengendalian administrasi sumber daya yang diperlukan. Untuk melaksanakan tugasnya, kegiatan-kegiatan penelitian dan pengabdian kepada masyarakat yang bersifat multidisiplin dilakukan oleh pusat-pusat penelitian dan pengembangan di lingkungan LPPM UPR, sedangkan kegiatan-kegiatan penelitian yang bersifat monodisiplin (Penelitian yang dilakukan secara mendalam pada suatu obyek tertentu) dilakukan oleh fakultasfakultas dan unit lain di lingkungan Universitas Palangka Raya, dengan prosedur administrasi dan saluran tetap melalui LPPM UPR.

Program aplikasi ini berfungsi sebagai pengganti proses pengusulan proposal penelitian dan pengabdian yang sebelumnya dilakukan secara manual dan akan dilakukan secara online (proposal online). Selain itu sistem dapat mengevaluasi proposal, penyampaian laporan kemajuan, pemantauan status proposal yang diajukan, serta mengumumkan informasi penting lainnya secara online.Usulan 


\section{JURNAL TEKNOLOGI INFORMASI}

proposal online dilakukan oleh operator LPPM atau pengusul secara mandiri namun tetap berkoordinasi dengan LPPM.

\subsection{Permasalahan yang akan diteliti}

Adapun rumusan masalah berdasarkan latar belakang yang telah diuraikan sebelumnya adalah sebagai berikut :

1. Bagaimana membangun sebuah sistem informasi berbasis website yang bertujuan untuk mengelola data usulan penelitian dan pengabdian serta menangani kendala yang ada seputar manajemen data usulan pada Lembaga Penelitian dan Pengabdian kepada Masyarakat di Universitas Palangka Raya?

2. Bagaimana merancang sebuah sistem yang dapat mempermudah proses pengajuan usulan serta penilaian dan peninjauan proposal penelitian dan pengabdian secara online pada Lembaga Penelitian dan Pengabdian kepada Masyarakat di Universitas Palangka Raya?

\section{Metode Penelitian}

a. Metode Pengumpulan Data

Pengumpulan data dilakukan untuk memperoleh informasi yang dibutuhkan melalui pengamatan dan pencatatan data-data untuk tujuan pengembangan program. Medode pengumpulan data yang digunakan adalah sebagai berikut:

1. Observasi

Observasi diterapkan dengan melakukan peninjauan langsung ke lokasi penelitian

2. Studi Literatur

Studi literatur diterapkan dengan melakukan pencarian informasi berupa referensi-refrensi, baik melalui buku-buku, artikel, maupun internet, mengenai metode pengembangan web.

\section{Hasil dan Pembahasan}

\subsection{Analisis Sistem}

Tahap ini melakukan identifikasi atau analisis kebutuhan sistem yang diperlukan dalam membangun aplikasi sistem informasi pengelolaan data penelitian

dan pengabdian berbasis website. Selain dapat memproses pengajuan proposal penelitian oleh dosen pengusul, sistem juga dapat melakukan plotting reviewer yang prosesnya dilaksanakan oleh operator, melakukan evaluasi atau penilaian proposal yang dilaksanakan oleh reviewer (penilai), serta proses pengurutan peringkat proposal yang berhak lulus seleksi yang dilakukan oleh sistem secara otomatis pada tahap penentuan ranking. Langkah-langkah yang dilakukan untuk membangun aplikasi ini adalah menentukan spesifikasi masukan yang diperlukan sistem, keluaran yang dihasilkan sistem, dan proses yang dibutuhkan.

\subsection{Analisis Kebutuhan Sistem}

Analisis Kebutuhan sistem dibutuhkan untuk menunjang penerapan sistem pada aplikasi. Sistem baru yang hendak diterapkan pada aplikasi harus sesuai dengan kebutuhan. Secara umum, aplikasi ini dibuat untuk mempermudah pekerjaan para pegawai di kantor LPPM Universitas Palangka Raya dalam hal mengelola data-data penelitian dan pengabdian serta untuk menunjang kinerja penelitian dosen di Universitas Palangka Raya. Adapun tahap-tahap yang perlu dikerjakan sebelum membuat aplikasi ini adalah dengan melakukan analisis kebutuhan sistem yang hendak dibuat.

\subsection{Rancangan Alur Sistem}

Rancangan alur sistem secara umum dibuat dengan tujuan memberikan gambaran kepada pengguna tentang alur langkah demi langkah kegiatan pada sistem yang tengah diusulkan. Adapun rancangan alur sistem berikut bukanlah inovasi ataupun rancangan baru dari sebuah sistem lama 
yang berlaku di LPPM UPR sebelumnya, namun merupakan adaptasi dari sebuah sistem informasi manajemen penelitian dan pengabdian yang berskala nasional (SIPLITABMAS) berbasis website, kemudian dibangunlah sistem informasi dengan tujuan yang serupa yaitu untuk mengelola pengusulan penelitian dan pengabdian kepada masyarakat, khusus di lingkungan Universitas Palangka Raya yang dilakukan secara online melalui website.

Adapun pengguna-pengguna sistem informasi pengelolaan penelitian dan pengabdian (SIPLITABMAS) ini dibagi menjadi 4 kategori, yaitu Admin, Operator, Reviewer (Penilai), dan Dosen Pengusul. Berikut adalah penjelasan mengenai tugas dan kegiatan masing-masing dari kelima pengguna tersebut :

1. Admin

Administrator atau biasa disebut admin merupakan pengguna yang bertanggung jawab untuk mengelola seluruh informasi yang disampaikan serta melakukan pemantauan terhadap sistem.

2. Operator

Operator LPPM merupakan pengguna komputer atau operator sistem yang bertugas mengoperasikan website SIPLITABMAS dan mengelola data tertentu, mengoperasikan komputer, serta peralatan pendukung lainnya.

3. Reviewer

Reviewer atau Penilai adalah pengguna yang notabennya merupakan tim pakar perguruan tinggi atau ahli dalam bidangnya bertugas untuk memberikan evaluasi atau penilaian terhadap proposal milik dosen.

\subsection{Modeling (Pemodelan)}

Proses Modeling ini akan menerjemahkan syarat kebutuhan ke sebuah perancangan software yang dapat diperkirakan sebelum masuk ke tahap pengkodean.

\subsubsection{Perancangan DFD (Data Flow Diagram)}

Penggambaran arsirtektur sistem yang digunakan dalam membangun Website Sistem Informasi Pengelolaan Data Penelitian dan Pengabdian di Universitas Palangka Raya adalah dengan menggunakan Data Flow Diagram.

1. DFD Diagram Konteks

Diagram Konteks digunakan untuk menggambarkan sistem secara garis besar atau keseluruhan. Diagram konteks Website Sistem Informasi Pengelolaan Data Penelitian dan Pengabdian pada Universitas Palangka Raya dapat dilihat pada Gambar 1.

2. Desain Navigasi

Desain navigasi sistem SIPLITABMAS ini adalah dengan menggunakan sitemap, yaitu alat bantu yang mempermudah dalam pengenalan peta situs dalam website. Dalam website SIPLITABMAS ini terdiri atas beberapa sitemap antara lain Sitemap Administrator, Sitemap Operator, Sitemap Reviewer, dan Sitemap Pengusul.

a. Administrator

Deskripsi Sitemap Admin website SIPLITABMAS pada LPPM Universitas Palangka Raya, dapat dilihat pada gambar 2 .

b. Reviewer

Deskripsi Sitemap Reviewer website SIPLITABMAS pada LPPM Universitas Palangka Raya, dapat dilihat pada gambar 3.

3. Desain User Interface (Antarmuka Pengguna)

User Interface atau antarmuaka merupakan mekanisme komunikasi antara pengguna dengan sistem. User interface pemakai dapat menerima informasi dari pengguna dan memberikan informasi kepada pengguna. 


\section{JURNAL TEKNOLOGI INFORMASI}

[E-ISSN 2656-0321]

[Vol 12. No. 1]

Jurnal Keilmutan dan Aplikasi Bidang Teknik Iniormatika

[Januari 2018]

1. Desain User Interface Admin

i. Form Login

Form Login merupakan halaman yang digunakan sebagai tindakan pengamanan terhadap sistem agar tidak dapat diakses oleh sembarang pengguna melainkan hanya dapat diakses oleh petugas yang berwenang mengakses SIPLITABMAS. Gambar 4 adalah desain form login pada website.

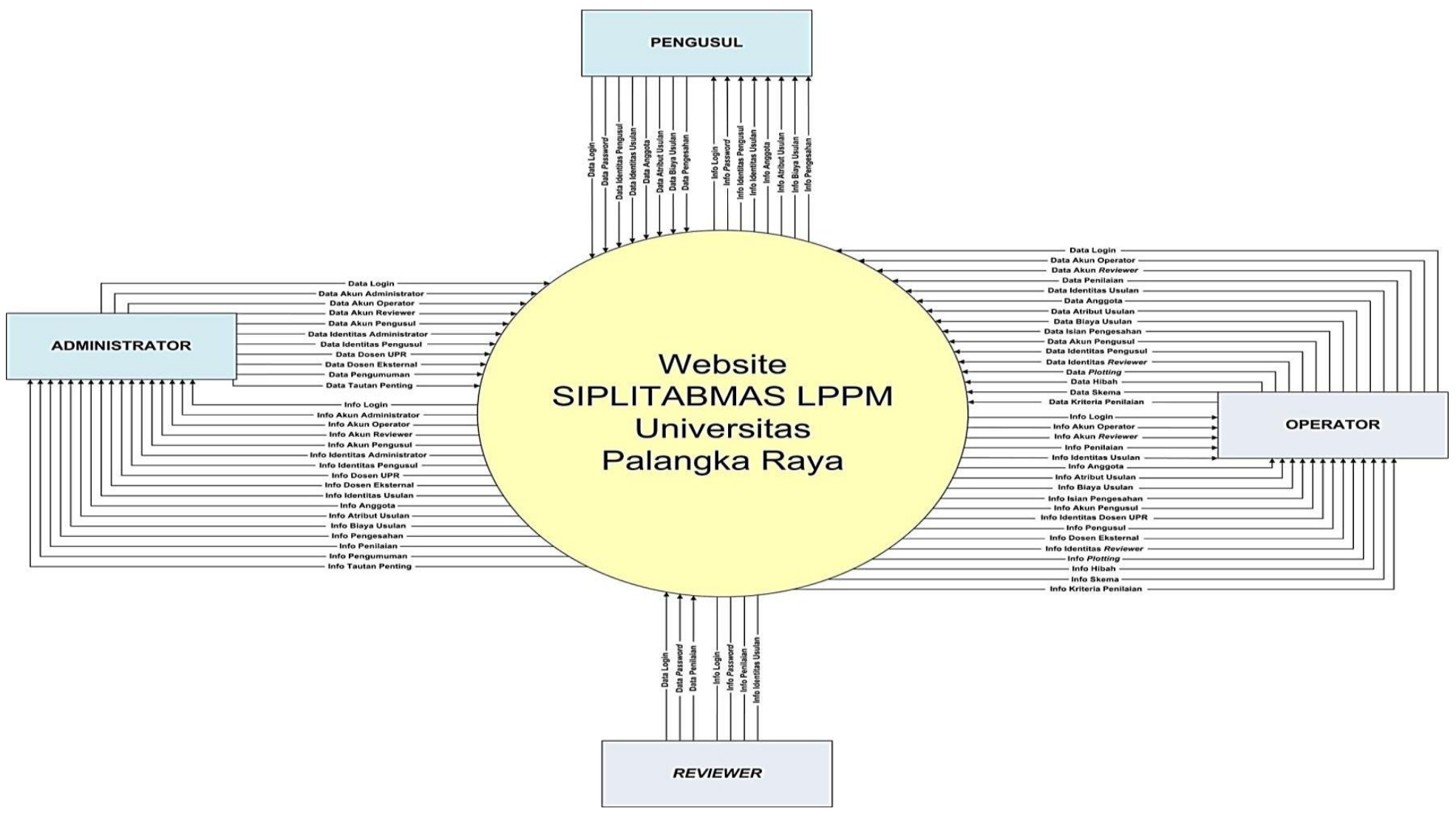

Gambar 1. Diagram Konteks SIPLITABMAS 


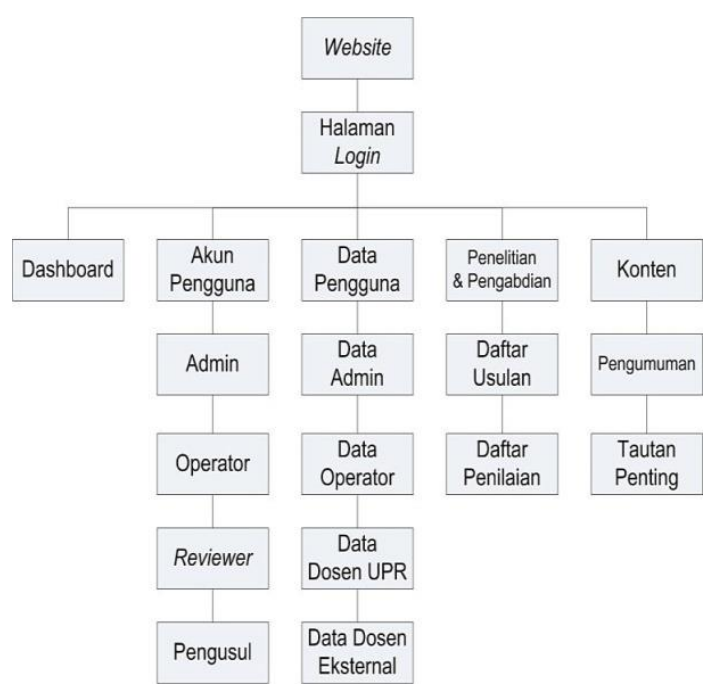

Gambar 2. Sitemap Administrator

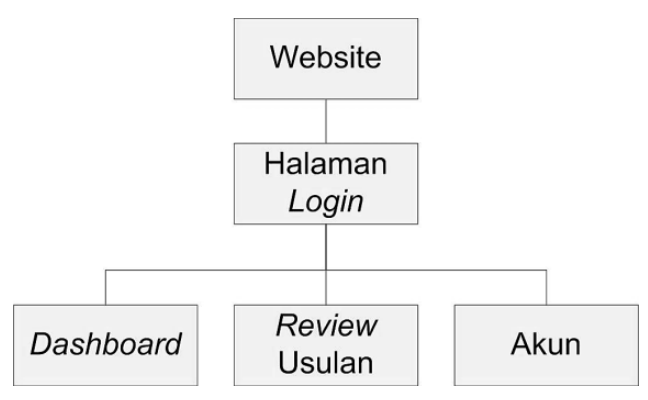

Gambar 3. Sitemap Reviwer

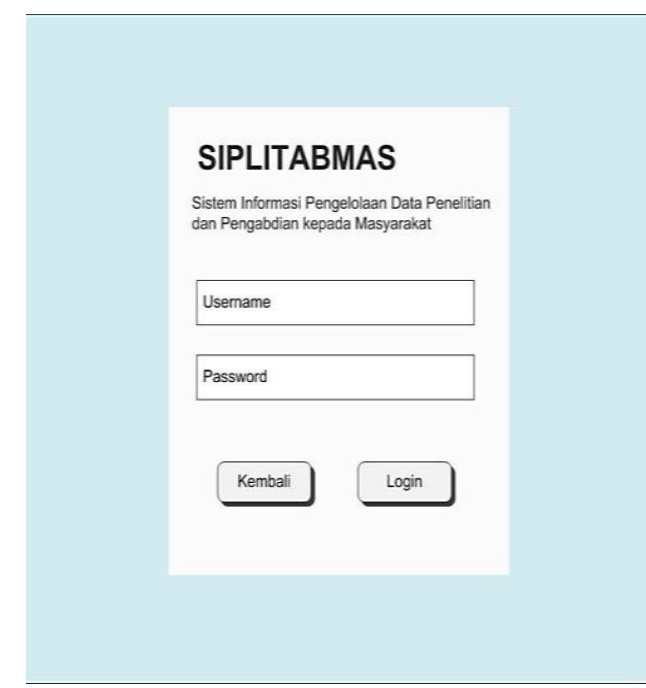

Gambar 4. Halaman Login 


\section{JURNAL TEKNOLOGI INFORMASI}

[E-ISSN 2656-0321]

[Vol 12. No. 1]

Jurnal Keilmutan dain Apilikasi Bidang Teknik Iniormatika

\subsection{Implementasi}

Implementasi dan pengujian dilakukan untuk membuktikan apakah Sistem Informasi Pengelolaan Data Penelitian dan Pengabdian (SIPLITABMAS) yang dibangun telah berfungsi, sehingga diperlukan skenario uji coba untuk. Tujuan dari tahap implementasi adalah untuk menerapkan konsep rancangan yang telah dibuat pada tahapan analisis dan desain sebelumnya serta sebagai simulasi dari penerapan Sistem Informasi Pengelolaan Data Penelitian dan Pengabdian yang dikembangkan.

\subsubsection{Implementasi Antarmuka}

Antarmuka atau interface merupakan bagian dari apliksi yang menyediakan sarana bagi pengguna untuk dapat berkomunikasi melalui interaksi visual. Implementasi antarmuka untuk perancangan tampilan awal aplikasi adalah sebagai berikut:

1. Implementasi Beranda Website

Gambar 5 berikut merupakan implementasi beranda website (Homepage), yaitu halaman muka yang pertama kali diakses oleh setiap pengguna sistem sebagai proses awal dalam melakukan pengelolaan. Adapun pada beranda website terdapat fitur untuk download pengumuman, tautan penting, akses untuk login, serta informasi kontak dan alamat menganai instansi LPPM. 


\section{JURNAL TEKNOLOGI INFORMASI}

[E-ISSN 2656-0321]

[Vol 12. No. 1]

\section{Jurnal Keilmutan dan Aplikasi Bidang Teknik Informatikna}

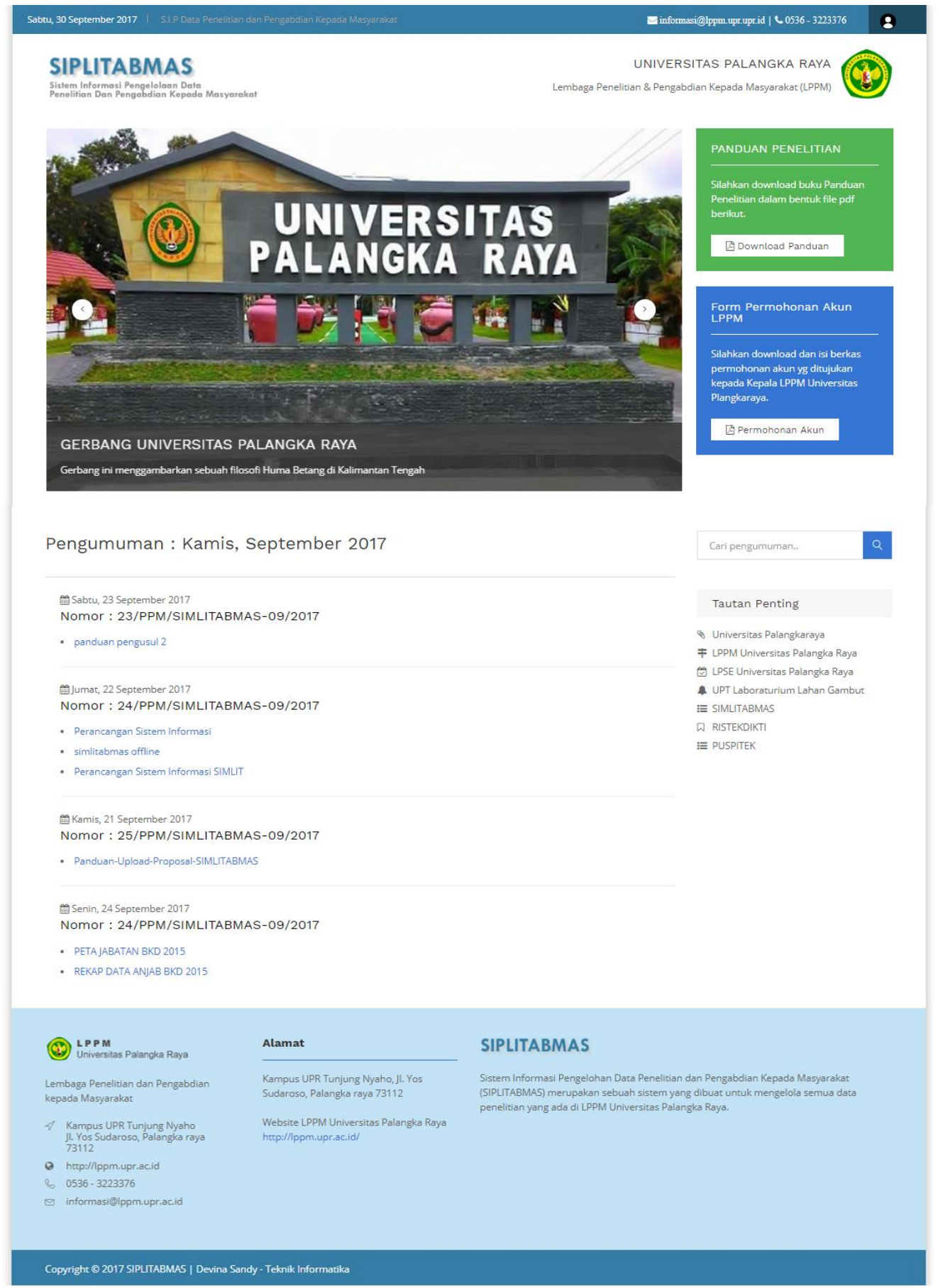

Gambar 5. Implementasi Beranda Website

2. Implementasi Detail Penilaian

Gambar 6 merupakan implementasi Detail Penilaian, dimana pada form detail ini, Reviewer menginputkan nilai berdasarkan poin kriteria yang tercantum pada form tersebut. Adapun poin-poin kriteria yang tercantum pada form adalah berdasarkan skema pengusulannnya. 
Detail Review Usulan

REVIEWER (1) | Prof. Dr. Ir. Arief Prajitno, M.S

No Kriteria Penilaian

1

Masalah yang diteliti: (Kontribusi pada iptek-sosbud, Perumusan masalah dalam kaitannya dengan renstra penelitian perguruan tinggi ybs]

2

3 Dukungan dana (incash/in kind) dari internal perguruan tinggi

4 Keutuhan peta jalan penelitian

5 Potensi tercapainya luaran: (Temuan baru (teori, metoda, kebijakan), dan Publikasi, HKI, buku ajar, model/kebijakan) dan lainlain

Jumlah

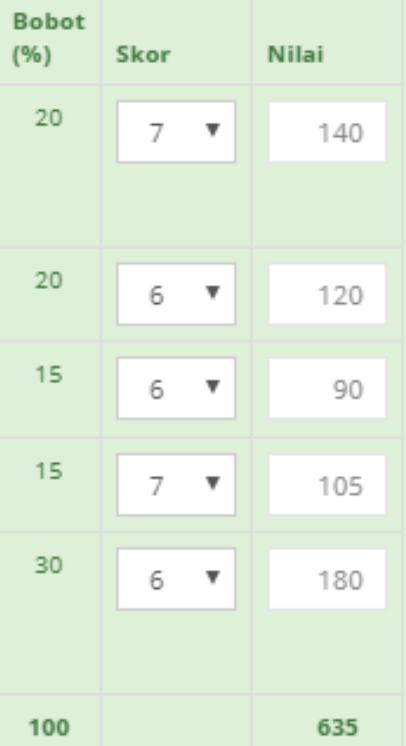

Skor: 1:Sangat Buruk, 2-Sangat Kurang, 3:Kurang, 5:Cukup, 6:Baik, 7:Sangat Baik

Rekomendasi

Dana

Rp. 20000000

Komentar

Gagasan dan ide penelitian sudah bagus, namun sebenarnya dapat lebih dikembangkan lagi.

DUpdate

Gambar 6. Implementasi Detail Review Usulan 


\subsection{Pengujian Sistem}

Pengujian merupakan bagian proses yang bertujuan untuk menemukan berbagai kesalahan atau kekurangan pada perangkat lunak yang hendak diuji. Pengujian bermaksud untuk mengetahui apakah perangkat lunak yang dibuat telah memenuhi kriteria yang sesuai dengan tujuan perancangan perangkat lunak tersebut.Adapun pengujian dilakukan dengan melibatkan pegawai kantor LPPM Universitas Palangka Raya sebagai penguji sistem dengan menguji satu-persatu seluruh operasi dan mencantumkan hasil pengujian di tabel hasil pengujian. Berdasarkan hasil pengujian terhadap Sistem Informasi Pengelolaan Data Penelitian dan Pengabdian (SIPLITABMAS) Berbasis Website pada Universitas Palangka Raya, dapat ditarik kesimpulan bahwa tidak ada kesalahan dalam pemrosesan mengelola data. Dengan kata lain, seluruh fungsi dalam sistem dapat berjalan dengan baik dan sesuai dengan tujuan awal fungsi tersebut dibuat. Erorr Handling pada sistem bekerja dengan baik untuk mencegah redudansi data, data yang salah dan tidak sesuai, serta keambiguitasan data. Meskipun secara keseluruhan sistem dapat berjalan dengan baik, tetapi tidak dapat dipungkiri bahwa mungkin akan ditemukan kesalahan dan error dikarenakan kekompleksitasan data dan banyaknya jumlah tabel. Oleh sebab itu, perawatan sistem (maintenance) diperlukan untuk memantau keberlangsungan sistem.

Berdasarkan hasil pengujian yang telah dilakukan, secara fungsional sistem telah menghasilkan output yang diharapkan, sehingga dapat dikatakan bahawa sistem informasi yang dibangun telah memenuhi tujuan awal pembanguanan perangkat lunak.

\section{PENUTUP}

\subsection{Kesimpulan}

Kesimpulan yang didapat dari penulisan Laporan Tugas Akhir dengan judul "Sistem Informasi Pengelolaan Data Penelitian dan Pengabdian (SIPLITABMAS) Berbasis Website pada Universitas Palangka Raya" adalah sebagai berikut :

1. Sistem Informasi Pengelolaan Data Penelitian dan Pengabdian Berbasis Website pada Universitas Palangka Raya dibangun menggunakan pemrograman PHP 5 dengan syarat dan ketentuan yang mengacu pada Buku Panduan Pelaksanaan Penelitian Dan Pengabdian Kepada Masyarakat di Perguruan Tinggi Edisi XI Tahun 2017 dan dengan mengadaptasi alur proses pada sistem lama. SIPLITABMAS ini dibangun dengan alur dimana pengelolaan data usulan ditangani oleh Admin dan Operator. Sementara Pengusul berkewajiban untuk mengajukan data usulan serta data lainnya yang berelasi. Data usulan yang telah masuk ke sistem kemudian didistribusi kepada Reviewer yang bertugas untuk memberikan penilaian terhadap usulan yang sesuai dengan kompetensinya.

2. Tahapan desain penelitian yang digunakan dalam merancang website SIPLITABMAS yaitu dimulai dengan tahap pencarian dan pengumpulan informasi, kemudian melakukan identifikasi masalah, menganalisis dan mendefinisi kebutuhan, membuat pemodelan menggunakan DFD (Data Flow Diagram) dan ERD (Entity Relationship Diagram), kemudian melakukan desain arsitektur sistem baru yang terdiri atas desain database, desain interface, desain navigasi, selanjutnya melakukan pengkodean, pengujian unit dan sistem menggunakan pengujian blackbox, serta tahapan yang terakhir adalaha operasi dan pemeliharaan sistem.

\subsection{Saran}

Beberapa saran yang bertujuan untuk perbaikan maupun peningkatan Sistem Informasi Pengelolaan Data Penelitian dan Pengabdian (SIPLITABMAS) Berbasis Website pada Universitas Palangka Raya,ini yaitu :

SIPLITABMAS yang diberlakukan untuk lingkungan Universitas Palangka Raya ini masih dapat dikembangkan menjadi sistem yang jauh lebih kompleks dan luas. Pengembangan ini terkait dengan fitur Monitoring kemajuan pelaksanaan usulan penelitian dan pengabdian yang telah terpilih 


\section{JURNAL TEKNOLOGI INFORMASI}

[E-ISSN 2656-0321]

[Vol 12. No. 1]

Jurnal Keilmuin dan Apikasi Bidang Teknik Informatikika

[Januari 2018]

untuk didanai. Pada tahap Monitoring ini, terdapat fitur untuk mengunggah catatan harian, laporan kemajuan, dan laporan akhir penelitian yang dilakukan secara bertahap dan mandiri oleh setiap tim penelitian. Dengan meluasnya fitur sistem SIPLITABMAS, maka pengguna sistem pun bisa menjadi lebih kompleks, seperti contohnya bertambah akun untuk pengguna Pemonitor, yaitu pengguna yang bertugas untuk memonitor berlangsungnya penelitian.

\section{DAFTAR PUSTAKA}

[1] Wang, H.-I. (2013). Toward a Green Campus with the Internet of Things - the Application of Lab Management. Proceedings of the World Congress on Engineering 2013 Vol II, (p. 1). London.

[2] Varmesan, O. (2015). Internet Of Things Beyond the Hype : reserach, Innovation, and Deployment.

[3] Susantok, M., Kurniawan, A., \& Azwar, H. (2013). Wifi Positioning System (WPS) Menggunakan Algoritma NeuralNetwork Backpropagation di Area Kampus Politeknik Caltex Riau. Jurnal Teknik Elektro dan Komputer, Vol.I, No. 2, Oktober2013, 130-141.

[4] Penalba, J. (2015, April 13). http://nixgeneration.com/. Retrieved from http://nixgeneration.com/ jaime/netdiscover/

[5] Viswanathan, P. (2015, April 13). about.com. Retrieved from http://mobiledevices.about.com/od/glossary/g/What-Is-A-Mobile-Device.htm 